\title{
The Role of Temperature in COVID-19 Disease Severity and Transmission Rates
}

\author{
Dominique Kang ${ }^{1}$, Clifford Ellgen ${ }^{1}$ \\ ${ }^{1}$ Pacific Theoretical Physics and Mathematics Research, Pasadena, CA, USA \\ Correspondence: cellgen@alumni.caltech.edu
}

\section{Highlights}

- SARS-CoV-2 loses infectivity at normal core body temperature $\left(37^{\circ} \mathrm{C}\right)$, but viral stability may increase substantially with small decreases in temperature proximate to $37^{\circ} \mathrm{C}$.

- Even air as warm as $25^{\circ} \mathrm{C}$ cools URT surfaces to several degrees below body temperature, which may make the URT exceptionally conducive to SARS-CoV-2 replication. Increased URT viral growth may contribute to higher transmission rates and more severe disease.

- Low core body temperature may enable more rapid SARS-CoV-2 growth, resulting in more severe disease. This may help explain higher case fatality rates among men and elderly people. 


\section{Abstract}

Air temperature and body temperature may influence COVID-19 disease severity and transmission rates. In vitro data indicate that SARS-CoV-2 loses infectivity at normal core body temperature $\left(37^{\circ} \mathrm{C}\right)$; however, small reductions in temperature proximate to $37^{\circ} \mathrm{C}$ may result in substantially increased viral stability. If these results are representative of viral decay rates in vivo, then cooler temperatures in the body may enable more rapid viral growth. Breathing cool air-even as warm as $25^{\circ} \mathrm{C}$-cools upper respiratory tract (URT) surfaces to several degrees below body temperature, and these lower temperatures may make the URT exceptionally conducive to SARS-CoV-2 replication. Increased URT viral load may enable more effective transmission. Additionally, because SARS-CoV-2 infection may frequently begin in the URT before spreading through the body, an increased rate of viral replication in the URT early in the disease course may result in more rapid progression of disease, potentially causing more severe adverse outcomes. Core body temperature may also be a factor in disease severity, as lower core body temperatures may enable more rapid viral growth. The significance of air temperature and body temperature to disease severity and transmission rates may inform preventative measures and post-exposure prophylaxis treatments for COVID-19.

\section{Graphical Abstract}

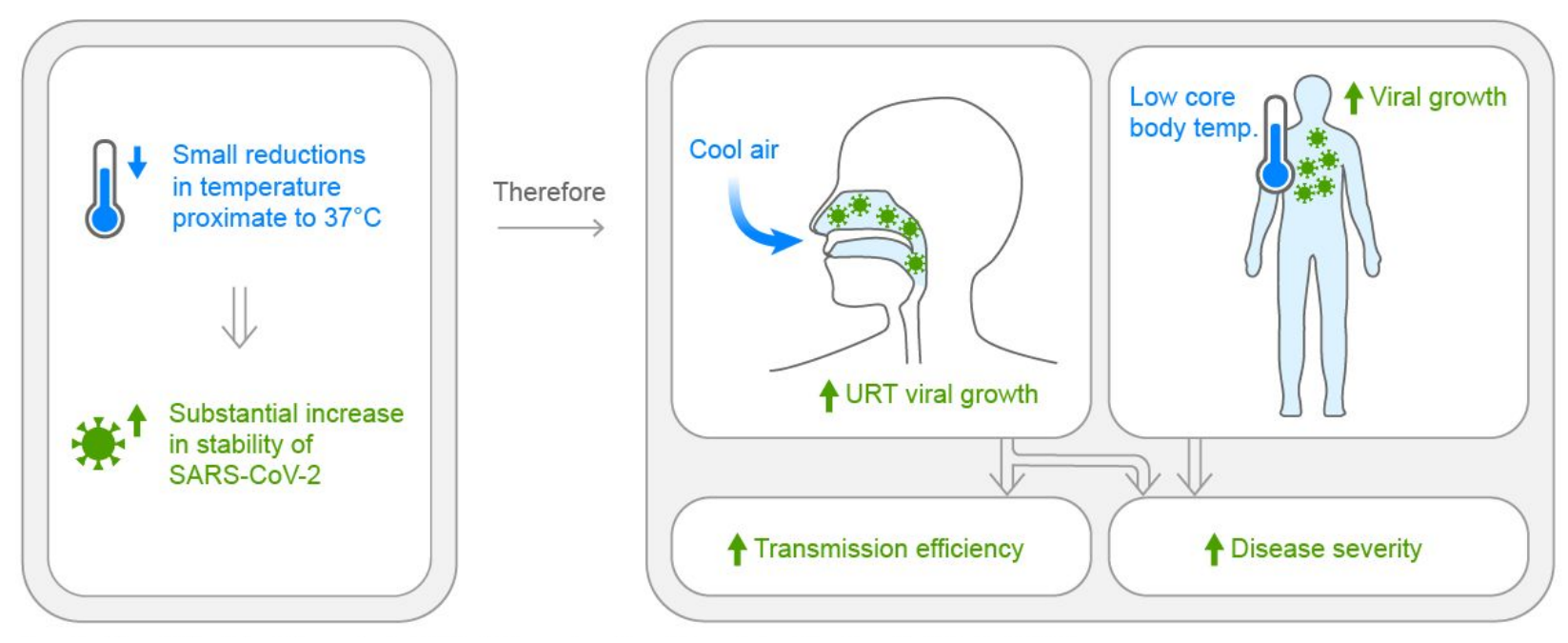

The relationships pictured are hypothesized based on available data. Further research is needed to validate these hypotheses. 


\section{Introduction}

The infectivity of viruses is affected by changes in temperature, and the human coronavirus SARS-CoV-2, which causes coronavirus disease 2019 (COVID-19), is no exception. The stability of SARS-CoV-2 at temperatures close to normal core body temperature suggests that temperature may play a particularly significant role in the transmission and severity of COVID-19. In vitro data indicate that viral stability may be particularly sensitive to fluctuations around $37^{\circ} \mathrm{C}$. Variation of temperatures in the body and between individuals may therefore result in substantially different rates of viral growth.

A variety of factors can influence temperatures in the body. Air temperature stands out as particularly relevant because it can directly influence temperatures in the URT, an area that plays a key role in the transmission and pathogenesis of COVID-19. Additionally, core body temperatures vary between individuals and may also influence disease severity. This review examines the roles of air temperature and core body temperature in the transmission and severity of COVID-19.

\section{Effect of Temperature on Viral Viability}

- $\quad$ SARS-CoV-2 loses infectivity at normal core body temperature $\left(37^{\circ} \mathrm{C}\right)$, but viral stability may increase substantially with small decreases in temperature proximate to $37^{\circ} \mathrm{C}$.

As with other viruses, the stability of SARS-CoV-2 is affected by temperature. Higher temperatures increase the rate of viral decay. ${ }^{1}$ Differences in viral stability at temperatures proximate to body temperature are of particular interest because there is variation in temperature in the body, as well as variation in core body temperature between individuals. These variations may contribute to different rates of viral growth in the body, potentially having implications for transmission rates and patient outcomes.

While SARS-CoV-2 is extremely stable at room temperature $\left(20-25^{\circ} \mathrm{C}\right)$, laboratory data indicate reduced stability at normal core body temperature $\left(37^{\circ} \mathrm{C}\right){ }^{1,2}$ A study found that SARS-CoV-2 incubated in virus transport medium for 1 day at $22^{\circ} \mathrm{C}$ had only a 0.5 -log unit reduction in infectious titer; at $37^{\circ} \mathrm{C}$, there was a 3.5 -log unit reduction in infectious titer after 1 day. ${ }^{1}$ Higher temperatures were found to result in more rapid viral decay.

No data are yet available on the stability of SARS-CoV-2 at temperatures slightly below $37^{\circ} \mathrm{C}$, but such data are available for SARS-CoV-1, the virus that causes severe acute respiratory syndrome (SARS). SARS-CoV-1 is much more stable a few degrees below body temperature than it is at body temperature. A study found that incubating dried virus at $33^{\circ} \mathrm{C}$ on a nonporous surface at a relative humidity of $95 \%$ for 24 hours resulted in a 1 -log unit reduction in infectious titer, while incubation at $38^{\circ} \mathrm{C}$ resulted in a $3.4-\log$ unit reduction. ${ }^{3}$ The substantial difference in viral stability between $33^{\circ} \mathrm{C}$ and $38^{\circ} \mathrm{C}$ is particularly significant to viral replication in vivo because temperatures in the body can fluctuate within this temperature range. ${ }^{4,5}$ The same study furthermore found that incubation of SARS-CoV- 1 at $22-25^{\circ} \mathrm{C}$ for 24 hours resulted in a $0.75-\log$ reduction in infectious 
titer. Stated differently, there is only a 0.25 -log unit difference in reduction of infectious titer between $22^{\circ} \mathrm{C}$ and $33^{\circ} \mathrm{C}$ over 1 day; but, between $33^{\circ} \mathrm{C}$ and $38^{\circ} \mathrm{C}$, there is a 2.4 -log unit difference. This indicates that the reduction in viral stability is not linear with increases in temperature; rather, the impact of a temperature change on viral infectivity is greatly affected by the temperature at which that temperature change occurs. In particular, variations in temperature between 22 and $33^{\circ} \mathrm{C}$ have minute impacts on viral decay, while small decreases in temperature proximate to $38^{\circ} \mathrm{C}$ result in a large increase in viral stability.

In vitro studies indicate that SARS-CoV-1 and SARS-CoV-2 demonstrate similarity in viral stability at a wide range of temperatures, including room temperature ${ }^{2}$ and body temperature ${ }^{1,3}$ (Table 1). The similarity in viral stability at these temperatures suggests the possibility of similar stability at other temperatures, as well. Like SARS-CoV-1, SARS-CoV-2 may become substantially more stable as temperatures decrease from $38^{\circ} \mathrm{C}$ to $33^{\circ} \mathrm{C}$ and, at $33^{\circ} \mathrm{C}$, stability may be comparable to that at room temperature. This potential heat sensitivity based on SARS-CoV-1 data can be considered along with the aforementioned laboratory data on SARS-CoV-2: the rate of viral decay of SARS-CoV-2 is relatively rapid at $37^{\circ} \mathrm{C}^{1}$; viral stability may increase substantially as temperatures decrease from $37^{\circ} \mathrm{C}$ to $33^{\circ} \mathrm{C}$; and, at $33^{\circ} \mathrm{C}$, SARS-CoV-2 may be extremely stable, approximately as stable as it is at room temperature. The difference in viral decay rate between $37^{\circ} \mathrm{C}$ and $33^{\circ} \mathrm{C}$ may be about 2 to 3 -log units per day for virus incubated in solution in vitro. If SARS-CoV-2 is sensitive to heat in this way and if the rate of viral decay is similar in vivo, then viral growth in vivo could be substantially impacted by fluctuations in body temperature. In particular, the rate of viral growth could increase substantially as temperatures in the body fall below $37^{\circ} \mathrm{C}$. This is relevant to disease progression of COVID-19 because parts of the body-and for many individuals, the entire body-frequently fall below $37^{\circ} \mathrm{C}$.

Additional research may be necessary to determine whether the rates of viral decay in vitro are similar to those that would occur in vivo. The remainder of this review assumes that in vitro data are representative of in vivo viral decay rates and explores the possible impacts on transmission and disease severity. 
Table 1. Comparison of stability of SARS-CoV-1 and SARS-CoV-2 at various temperatures.

\begin{tabular}{|c|c|c|c|c|}
\hline $\begin{array}{l}\text { Temperature } \\
\text { range }\end{array}$ & Virus & Condition & $\begin{array}{l}\text { Reduction in } \\
\text { infectious titer } \\
\left(\log _{10}\right)\end{array}$ & Study \\
\hline \multirow[t]{3}{*}{$\begin{array}{l}\text { Room } \\
\text { temperature }\end{array}$} & $\begin{array}{l}\text { Both } \\
\text { SARS-CoV-1 \& } \\
\text { SARS-CoV-2 }\end{array}$ & $\begin{array}{l}21-23^{\circ} \mathrm{C} \text { in aerosols and } \\
\text { on various surfaces }\end{array}$ & $\begin{array}{l}\text { Similar under all } \\
\text { circumstances } \\
\text { tested }\end{array}$ & $\begin{array}{l}\text { Van } \\
\text { Doremalen et } \\
\mathrm{al}^{2}\end{array}$ \\
\hline & SARS-CoV-1 & $\begin{array}{l}1 \text { day at } 22-25^{\circ} \mathrm{C} \text {; dried } \\
\text { virus on a nonporous } \\
\text { surface at a relative } \\
\text { humidity of } 40-50 \% \\
\text { (found to produce } \\
\text { similar results to virus } \\
\text { in solution for the } \\
\text { conditions tested) }\end{array}$ & $0.75 \pm 0.5$ & Chan et $\mathrm{al}^{3}$ \\
\hline & SARS-CoV-2 & $\begin{array}{l}1 \text { day at } 22^{\circ} \mathrm{C} \text {; incubated } \\
\text { in virus transport } \\
\text { medium }\end{array}$ & $0.5 \pm 0.05$ & Chin et $\mathrm{al}^{1}$ \\
\hline \multirow[t]{2}{*}{$\begin{array}{l}\text { Core body } \\
\text { temperature }\end{array}$} & SARS-CoV-1 & $\begin{array}{l}1 \text { day at } 38^{\circ} \mathrm{C} \text {; dried } \\
\text { virus on a nonporous } \\
\text { surface at a relative } \\
\text { humidity of } 95 \% \text { (found } \\
\text { to produce similar } \\
\text { results to virus in } \\
\text { solution for the } \\
\text { conditions tested) }\end{array}$ & $3.4 \pm 0.5$ & Chan et $\mathrm{al}^{3}$ \\
\hline & SARS-CoV-2 & $\begin{array}{l}1 \text { day at } 37^{\circ} \mathrm{C} \text {; incubated } \\
\text { in virus transport } \\
\text { medium }\end{array}$ & $3.2 \pm 0.05$ & Chin et $\mathrm{al}^{1}$ \\
\hline
\end{tabular}



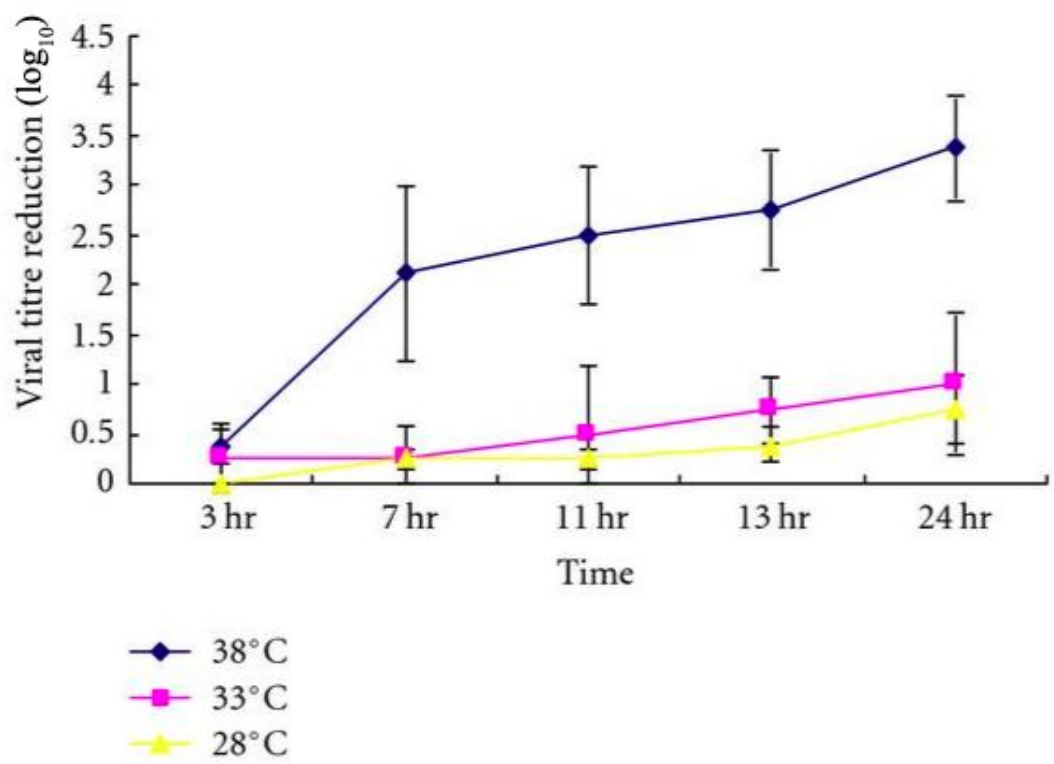

Figure 1. Infectivity of SARS-CoV-1 at different temperatures on a nonporous surface with relative humidity $>95 \%$ (which was found to produce similar results to virus in solution). Stability of SARS-CoV- 1 at $38^{\circ} \mathrm{C}$ is similar to that of SARS-CoV-2 at $37^{\circ} \mathrm{C}$, and stability of SARS-CoV-1 at $28^{\circ} \mathrm{C}$ is similar to that of SARS-CoV-2 at $22-25^{\circ} \mathrm{C}$. (The differences in temperatures of these comparisons is a result of the limited set of temperatures that have been tested; the differences do not imply dissimilarity in stability.) It is possible that stability of SARS-CoV-1 and SARS-CoV-2 is also similar near $33^{\circ} \mathrm{C}$. Figure by Chan et al, $2011 .^{3}$ 


\section{Effect of Air Temperature on Disease Severity and Transmission Rates}

\section{Impact of Air Temperature on URT Viral Growth}

- Even air as warm as $25^{\circ} \mathrm{C}$ cools URT surfaces to several degrees below body temperature, which may make the URT exceptionally conducive to SARS-CoV-2 replication.

The surfaces of the URT are often in a temperature range that may correspond to relative SARS-CoV-2 stability. When breathing air below body temperature, the temperature of the airstream is warmed by the body until it reaches body temperature, and this process cools the airways. Breathing air at $25^{\circ} \mathrm{C}$ (the upper end of room temperature) lowers the nasal valve area to $30^{\circ} \mathrm{C}$ and the nasopharynx to $34^{\circ} \mathrm{C} .{ }^{4}$ The airstream ordinarily rises to within $0.5^{\circ} \mathrm{C}$ of body temperature before reaching the trachea, ${ }^{6}$ making lower temperatures unique to the URT.

This relatively small change in temperature may have a substantial impact on the rate of viral growth in the URT. As described previously, viral stability may increase substantially as temperature falls below $37^{\circ} \mathrm{C}$, and, at $33^{\circ} \mathrm{C}$, SARS-CoV-2 may be extremely stable. Furthermore, SARS-CoV-2 likely replicates effectively in URT epithelium: SARS-CoV-2 uses the SARS-CoV-1 receptor human angiotensin-converting enzyme 2 (ACE2) to obtain entry into host cells, which suggests the two viruses may target similar cells ${ }^{7,8}$; and in vitro data indicate that SARS-CoV-1 replicates productively on the nasal epithelium. ${ }^{9}$ High URT viral loads have moreover been observed in COVID-19 patients. $^{10,11}$ The relatively cool temperature of URT surfaces may therefore make the nasal epithelium an exceptionally suitable environment for SARS-CoV-2 replication and spread.

COVID-19 patients often develop fever, ${ }^{12,13}$ and this heat may suppress viral growth. However, fever does not heat URT surfaces as effectively as it does other areas of the body. Inhaled air begins at ambient temperature at the nostrils and converges to the patient's body temperature as it moves through the airway. ${ }^{4}$ As such, URT surfaces are cooled by the inhalation of air below body temperature, even in a feverish patient.

\section{Impact of Air Temperature on Transmission Rates}

- By contributing to increased URT viral load, cooler air temperatures may enable more efficient transmission.

The increase in URT viral growth enabled by cooler air temperatures may be relevant to COVID-19 transmission rates, as higher viral load in the URT could enable more efficient transmission. The primary mode of transmission of COVID-19 is currently thought to be direct contact of mucous membranes (eyes, nose, mouth) with infectious respiratory droplets and through exposure to fomites. ${ }^{14-16}$ Higher viral load in the URT could result in higher viral titer in respiratory droplets expelled by an infected host. Higher URT viral load may also increase efficiency of transmission via 
fomites. Fomites can become contaminated through contact with body secretions from infected hosts, and higher URT viral load could result in an increased concentration of virus in the initial inoculum. The increased viral titer on fomite surfaces could enable more efficient transmission to naive hosts. In addition, increased initial titer of inoculum prolongs viral survival on fomite surfaces, increasing the duration of time over which those fomites would remain contaminated. ${ }^{17}$ This hypothesized relationship of URT viral load and transmission rate is supported by data from an animal study: A study on ferrets infected with SARS-CoV-2 found that high URT virus titers resulted in efficient transmission to naive ferrets by direct contact and contributed to airborne transmission. ${ }^{18}$

We previously hypothesized that cooler air temperatures increase SARS-CoV-2 viral replication in the URT. If this is true, then one would expect temperature and transmission rates to be inversely correlated. Available data are consistent with this: Some studies have found that increases in outdoor temperature are associated with modest but significant decreases in COVID-19 transmission rates. ${ }^{19-23}$ Unfortunately, these studies must be interpreted with caution as they face issues with poor data quality and confounding factors. ${ }^{24,25}$ Furthermore, studies on outdoor temperature are of limited use in evaluating this hypothesis because they do not necessarily account for the actual air temperature breathed by a given population: In developed countries, people spend the vast majority of their time in temperature-controlled environments, ${ }^{26,27}$ and, in these countries, the majority of person-to-person transmission of respiratory viruses occurs indoors. ${ }^{28}$ Indoor air temperature may be relevant to transmission because comfortable indoor temperatures of $20-25^{\circ} \mathrm{C}$ are well within the temperature range that may correspond to increased SARS-CoV-2 replication in the URT. It could be valuable to study the relationship between the air temperature breathed by a population — which may be indoor or outdoor air temperature-and COVID-19 transmission rate.

When interpreting the studies on outdoor air temperature and transmission rates, one may conjecture that higher temperatures decreased viral survival on fomites by increasing the rate of viral decay, thereby contributing to decreases in transmission. While this would certainly be the case at some temperatures, the rate of viral decay is only trivially affected by increases in temperature until temperature is sufficiently high. Increasing the temperature from $4^{\circ} \mathrm{C}$ to $22^{\circ} \mathrm{C}$ results in a difference of $\leq 0.6$-log unit viral reduction per day for SARS-CoV-2 incubated in virus transport medium. ${ }^{1}$ If stability of SARS-CoV-2 is similar to SARS-CoV-1, the rate of viral decay would remain almost completely unchanged until temperatures exceed $33^{\circ} \mathrm{C}$. Three of the environmental studies that found inverse correlation between transmission rates and outdoor air temperature considered only temperatures $\leq 22^{\circ} \mathrm{C}^{20,21,23}$ SARS-CoV-2 is extremely stable in this range. An increased rate of viral decay on fomites due to increased outdoor air temperature is therefore unlikely to have contributed substantially to the observed decrease in transmission rates in these three studies. By contrast, breathing air at any temperature affects URT temperature and may thereby contribute to URT viral load and transmission rate. 


\section{Impact of Air Temperature on Disease Severity}

- Due to the significance of URT viral growth in the pathogenesis of COVID-19, temperature of air inhaled may impact COVID-19 disease severity.

While much remains to be understood about the pathogenesis of COVID-19, available data indicate that the rate of viral replication in the URT-especially during early stages of disease-may have a significant impact on disease severity. The progression of COVID-19 may be represented by three increasingly severe phases: (1) acute viral replication, wherein SARS-CoV-2 establishes infection and replicates primarily in the respiratory tract, typically causing mild symptoms (i.e. dry cough, headache, fever); (2) pulmonary involvement, wherein pneumonia develops and hypoxia may ensue; and (3) hyperactive immune response, wherein excessive cytokine production contributes to immune system dysregulation and severe adverse outcomes occur (i.e. acute respiratory distress syndrome [ARDS], systemic inflammatory response syndrome [SIRS], cardiac failure). ${ }^{29,30}$ The first phase is most relevant when considering the significance of URT infection in disease progression.

The relevance of URT infection may be elucidated by the pathogenic similarity of COVID-19 and SARS. The pathological features of the two diseases bear notable resemblance to each other. ${ }^{31,32}$ As current understanding is that both causal coronaviruses obtain entry into host cells utilizing ACE2, it is reasonable to assume that these two viruses infect similar cells. ${ }^{7,8}$ While differences between the two diseases are nontrivial, available data suggest that the two viruses may follow a similar path of viral growth and spread through the respiratory system in the initial phase of the disease course.

With SARS-CoV-1, replication typically first occurs in upper airway epithelial cells, and virus subsequently spreads to the lower respiratory tract, ${ }^{33}$ infecting tracheobronchial and alveolar epithelial cells. ${ }^{34}$ Viral spread to alveoli has been hypothesized to occur via airway surfaces: In vitro data indicate that SARS-CoV-1 replicates productively on the nasal and tracheobronchial epithelium (especially on ciliated epithelial cells) and sheds over time onto the luminal surface of the epithelium. ${ }^{9}$ The abundance of ACE2 on luminal surfaces of conducting airway epithelium may enable considerable and progressive viral growth and spread throughout the airways. ${ }^{7-9,34}$

Current evidence suggests that SARS-CoV-2 also infects airway epithelial cells early in the disease course: In confirmed COVID-19 patients, high viral titers are frequently observed in the upper and lower respiratory tracts early in infection. ${ }^{10,11}$ Given SARS-CoV-2 affinity for ACE2, the abundance of ACE2 on airway epithelium may support progressive viral growth and spread throughout the airways, as has been hypothesized to occur with SARS-CoV-1. These data suggest that SARS-CoV-2 may similarly establish infection in the URT and progressively replicate and spread through the airway epithelia.

We previously hypothesized that breathing cool air-even as warm as $25^{\circ} \mathrm{C}$-may make the URT exceptionally conducive to SARS-CoV-2 replication. The postulated pathogenesis suggests that breathing cool air-especially during early stages of infection-may contribute to more rapid escalation in disease severity. Data on viral load are consistent this hypothesis: URT viral load is 
strongly correlated with adverse outcomes and has been hypothesized to be a predictor of disease severity. ${ }^{10}$ The nasopharyngeal viral load of severe COVID-19 cases has been found to be about 60 times higher than that of mild cases. ${ }^{10}$

The stability of SARS-CoV-2 at the cool temperatures of the URT and its relative instability at normal core body temperature also suggest the possibility that the URT serves as a viral reservoir that enables continual reinfection of proximate airway surfaces, supporting repeated cycles of viral replication and spread through the airways. This would indicate that viral growth in the URT remains pathogenically significant even after infection has spread beyond the URT.

Conversely, warmer air temperatures may suppress viral replication in the URT. Given the role of URT infection in the pathogenesis of COVID-19, reducing the rate of viral replication in the URT during the early stages of establishment of COVID-19 may slow disease progression. Some have hypothesized that suppressing viral growth during the early stages of establishment of COVID-19 (i.e. prior to peak viral load and severe symptoms) may reduce duration of symptoms and prevent progression of severity. ${ }^{29,35,36}$

\section{Effect of Body Temperature on Disease Severity}

- Low core body temperature may enable more rapid viral growth, which may contribute to more severe disease.

The potentially substantial increase in SARS-CoV-2 stability with decreases in temperatures proximate to $37^{\circ} \mathrm{C}$ may have implications for individuals with low core body temperatures. Lower core body temperatures may support more rapid viral growth and thereby contribute to higher viral load, which is strongly correlated with disease severity. ${ }^{10,11}$ If this is the case, one would expect to see an increase in disease severity among individuals with unusually low body temperature. While we are unaware of any direct analysis of the relationship between these two factors, existing data are consistent with this possibility.

Emerging evidence indicate that the case fatality rate of COVID-19 is associated with age, sex, and comorbidities, including hypertension, diabetes, and cardiovascular disease. ${ }^{37-39}$ Higher case fatality rates among men has been hypothesized to be caused by sex-based immunological differences and gendered differences in behavior that produce comorbities (e.g. drinking and smoking) ${ }^{40}$ Higher case fatality rates among elderly people may be related to higher prevalence of comorbidities and age-related changes in the immune system. ${ }^{35,41}$ Another relevant factor in case fatality rate may be body temperature. There are substantially more men and elderly people with unusually low body temperatures than there are women and younger people, respectively. A large cross-sectional study found that mean body temperature is $0.17^{\circ} \mathrm{C}$ lower in men than in women, with the mean body temperature being $0.19^{\circ} \mathrm{C}$ lower in $80+$ year old women than in $20-29$ year old women, and $0.15^{\circ} \mathrm{C}$ lower in 80+ year old men than in 20-29 year old men. ${ }^{5}$ While these differences in mean body temperature are small, the relatively greater number of men and elderly with unusually low body temperature may be considerable: Measured body temperatures appear to be approximately 
normally distributed (Figure 2), and there is a significant multiplier effect that occurs when comparing two normal distributions with similar variance but slightly different mean.

To demonstrate this multiplier effect, assume the body temperatures of two populations $A$ and $B$ can be represented with two normal distributions (Figure 3). Let $A$ have a mean of $36.4^{\circ} \mathrm{C}$, and let $B$ have a mean that is $0.2^{\circ} \mathrm{C}$ lower, $36.2^{\circ} \mathrm{C}$. Let both $A$ and $B$ have a standard deviation of $0.6^{\circ} \mathrm{C}$. (These values were selected to be similar to measured values from the aforementioned study on body temperatures, but limitations in the data provided by the study prevent us from estimating precise values. ${ }^{5}$ As such, these numbers should be considered merely an example.) Let's say we want to know the number of people with unusually low body temperatures which-for the purposes of this example-we arbitrarily define as $\leq 35.5^{\circ} \mathrm{C}$, which is 1.5 standard deviations below the mean of distribution $A$. The frequency of body temperatures $\leq 35.5^{\circ} \mathrm{C}$ is $4.8 \%$ in population $A$ and $9.1 \%$ in population $B$. Stated differently, given a standard deviation of $0.6^{\circ} \mathrm{C}$, a $0.2^{\circ} \mathrm{C}$ decrease in mean body temperature results in a $90 \%$ increase in the number of people with unusually low body temperatures of $\leq 35.5^{\circ} \mathrm{C}$. The difference in frequency is even more pronounced as temperatures decrease: The frequency of body temperatures $\leq 35.0^{\circ} \mathrm{C}$ is $0.6 \%$ in population $A$ and $1.5 \%$ in population $B-$ a $150 \%$ increase.

Referring again to measured temperatures, ${ }^{5}$ the distributions appear to be approximately normally distributed with similar variances but slightly different means. This suggests that the number of people with low body temperature is considerably greater among men than women and among elderly people than young people. A calculation from the study supports this conjecture: Frequency of temperatures $<35.6^{\circ} \mathrm{C}$ in the $20-59$ age group is $6.9 \%$ in women and $11.8 \%$ in men-a $71 \%$ increase in frequency among men relative to women.

As described earlier, the heat sensitivity of SARS-CoV-2 suggests that viral stability may rapidly increase as temperatures decline from $37^{\circ} \mathrm{C}$ to $33^{\circ} \mathrm{C}$. As such, every incremental decrease in body temperature may enable a substantially greater rate of viral growth. Unusually low body temperature may therefore pose a significant risk factor for COVID-19. The considerably greater number of men and elderly people with unusually low body temperature and the relatively high case fatality rates observed in these populations are consistent with this hypothesis. This suggests that body temperature may be among the many factors associated with age and sex that may help explain the differences in COVID-19 case fatality rate.

On the other hand, obesity is positively correlated with COVID-19 morbidity ${ }^{42}$ but negatively correlated with mean body temperatures. The same body weight study found that the mean body temperature of obese participants was $0.16-0.28^{\circ} \mathrm{C}$ higher than normal weight participants of the same sex and age. ${ }^{5}$ While this data does not support the hypothesis that low body temperature increases likelihood of disease severity, this data also does not contradict the hypothesis because obesity is associated with higher prevalence of other comorbidities that have been found to be correlated with higher COVID-19 case fatality rates, such as hypertension, diabetes, and cardiovascular disease. ${ }^{43}$ Relevant factors such as these must be controlled for when evaluating the relationship of body temperature and COVID-19 morbidity and mortality. 

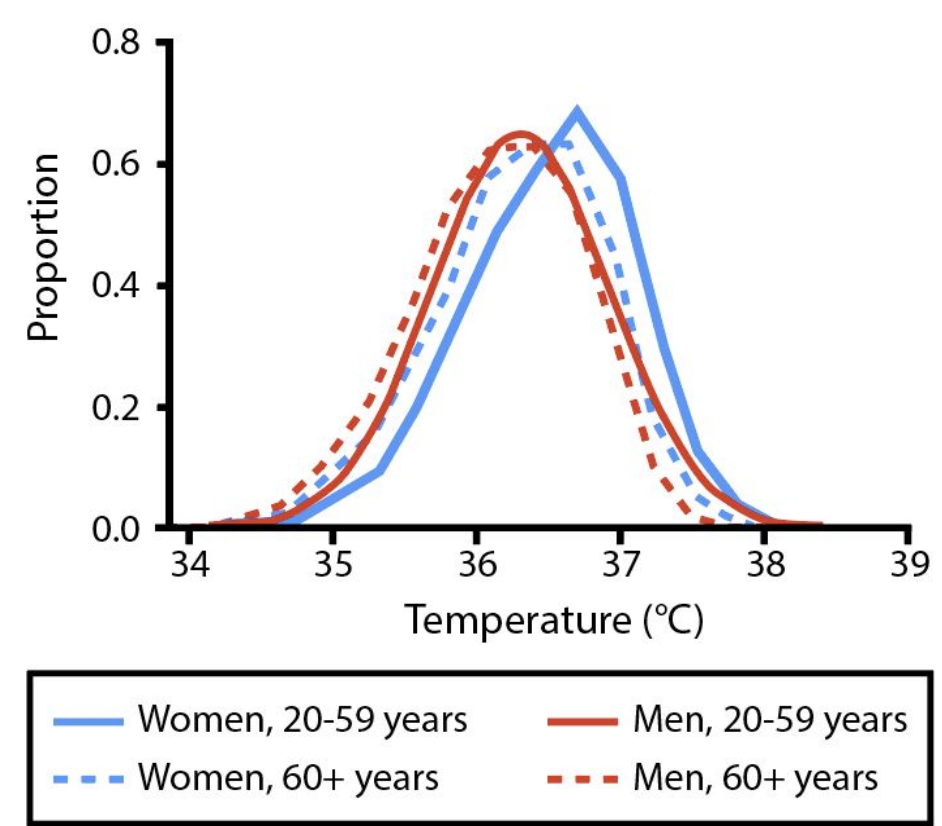

Figure 2. Distribution of measured body temperatures by age and sex. Adapted from figures by Waalen \& Buxbaum, 2011.

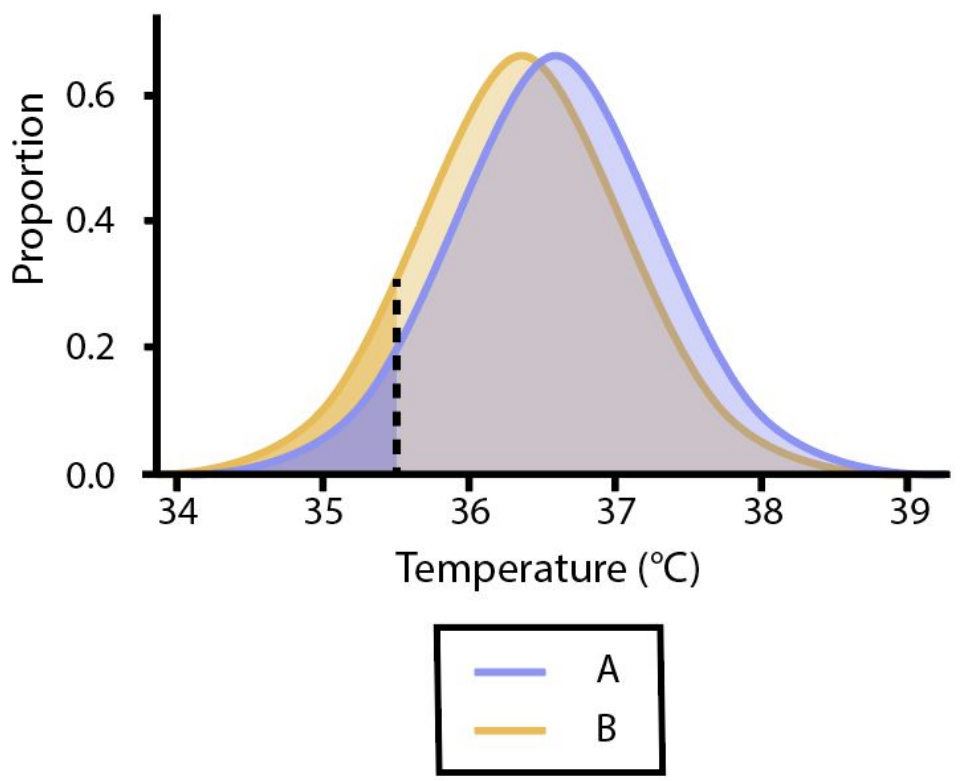

Figure 3. Distributions of body temperatures in two hypothetical populations, $A$ and $B$. The mean of $A$ is $36.4^{\circ} \mathrm{C}$, and the mean of $B$ is $36.2^{\circ} \mathrm{C}$. Both $A$ and $B$ have a standard deviation of $0.6^{\circ} \mathrm{C}$. Unusually low body temperatures are arbitrarily defined as $\leq 35.5^{\circ} \mathrm{C}$ (indicated by the dotted line), which is 1.5 standard deviations below the mean of $A$. 


\section{Concluding Remarks and Future Directions}

The heat sensitivity of SARS-CoV-2 suggests that cooler air temperatures and lower body temperatures may enable increased rates of viral growth in the body and thereby contribute to increased transmission rates and disease severity.

In vitro data indicate that SARS-CoV-2 loses infectivity at normal core body temperature $\left(37^{\circ} \mathrm{C}\right)$, but-like SARS-CoV-1-viral stability may increase substantially with small decreases in temperature proximate to $37^{\circ} \mathrm{C}$. Further research on how viral decay of SARS-CoV-2 is affected by small changes in temperature within a range that occurs in the body (i.e. $\sim 30-40^{\circ} \mathrm{C}$ ) would help elucidate the potential effect of temperature on viral growth in vivo. Such experiments should incubate virus in a medium that produces viral decay rates comparable to those which occur in vivo.

Even air as warm as $25^{\circ} \mathrm{C}$ cools URT surfaces to several degrees below body temperature, which may make the URT exceptionally conducive to SARS-CoV-2 replication. Animal studies may be useful in testing this hypothesis: Animals inoculated with SARS-CoV-2 could be kept at various air temperatures, and URT viral load could be tracked and analyzed for correlation with air temperature.

Because increased URT viral load likely enables more effective transmission, lower air temperatures may contribute to increased transmission of COVID-19. Several studies have analyzed correlation between outdoor air temperature and transmission rates; however, these studies are of limited use in evaluating the hypotheses proposed in this review because they do not account for indoor air temperature. People in developed nations spend the majority of their time in temperature-controlled environments, and even comfortable temperatures (e.g. $20-25^{\circ} \mathrm{C}$ ) cool the URT sufficiently to potentially impact viral growth, suggesting that indoor temperatures may impact transmission rates. Further research is necessary to quantify the potential impact of both outdoor and indoor air temperature on transmission rates; however, indoor air temperature data may be difficult to acquire. It may be more effective to study the impact of air temperature on URT viral load (perhaps using an animal study, as previously suggested) and infer impact on transmission rates.

Because SARS-CoV-2 infection may frequently begin in the URT before spreading through the body, lower temperatures of air inhaled-especially during early stages of infection-could contribute to increased disease severity. Conversely, warmer air may reduce the rate of viral growth in the URT. Suppressing URT viral replication would likely have a greater impact in preventing escalation of severity if suppression occurs when SARS-CoV-2 is mostly contained in the URT, immediately post-exposure or early in SARS-CoV-2 infection. This suggests that administration of warm air may potentially represent a therapeutic measure as a post-exposure prophylaxis and an early-stage treatment to prevent disease progression. Post-exposure prophylaxis applications may be of particular relevance for healthcare professionals who have insufficient personal protective equipment, as well as for populations who are at risk of more severe disease. 
Warm air delivery would likely need to occur over sustained periods of time to suppress viral replication to a degree that would be beneficial because decreases in virus infectivity are dependent on duration of exposure to elevated temperatures. Incubating SARS-CoV-2 in viral transport medium at $37^{\circ} \mathrm{C}$ results in a 1.5 -log unit reduction in infectious titer after 12 hours, a 3.5-log unit reduction after 24 hours, and a $\geq 6.8$-log unit reduction after 48 hours. ${ }^{1}$ Higher temperatures result in more rapid loss of viral stability: Just 10 minutes at $56^{\circ} \mathrm{C}$ results in a $3-\log$ unit reduction. ${ }^{1}$ It is important to note that air that is warmer than body temperature will be cooled during inhalation, limiting the effectiveness of very warm air in reducing viral stability in vivo. The impact of temperature on viral growth could be tested in an animal study by measuring URT viral load in animals infected with SARS-CoV-2 before and after exposure to air at various temperatures and durations.

Severity of COVID-19 may also be affected by core body temperature. The potentially substantial increase in SARS-CoV-2 stability as temperatures fall below $37^{\circ} \mathrm{C}$ suggests that lower core body temperatures could enable more rapid viral growth and thereby contribute to more severe disease. The prevalence of unusually low body temperatures among men and elderly people may help explain higher case fatality rates in these demographics. Research that determines the significance of this possible correlation could be of value. Such an analysis should consider a patient's normal core body temperature, which may be different from body temperature while the patient has COVID-19 since fever is a common symptom. Age, sex, BMI, and comorbidities should be controlled for. Large healthcare organizations may already be collecting this data, as they track patient data during regular visits and may have also treated COVID-19 patients.

The impact of temperatures in the body on viral growth may help explain COVID-19 transmission rates and disease severity. Advances made in understanding the various impacts of temperature on COVID-19 could inform both disease prevention and treatment, with potentially significant impacts on patient outcomes and global disease burden.

\section{References}

1. Chin AWH, Chu JTS, Perera MRA, et al. Stability of SARS-CoV-2 in different environmental conditions. Lancet Microbe. April 2020. doi:10.1016/S2666-5247(20)30003-3

2. van Doremalen N, Bushmaker T, Morris DH, et al. Aerosol and Surface Stability of SARS-CoV-2 as Compared with SARS-CoV-1. N Engl J Med. 2020;382(16):1564-1567. doi:10.1056/NEJMc2004973

3. Chan KH, Peiris JSM, Lam SY, Poon LLM, Yuen KY, Seto WH. The Effects of Temperature and Relative Humidity on the Viability of the SARS Coronavirus. Kohl A, ed. Adv Virol. 2011;2011:734690. doi:10.1155/2011/734690

4. Keck T, Leiacker R, Riechelmann H, Rettinger G. Temperature Profile in the Nasal Cavity. The Laryngoscope. 2000;110(4):651-654. doi:10.1097/00005537-200004000-00021

5. Waalen J, Buxbaum JN. Is Older Colder or Colder Older? The Association of Age With Body Temperature in 18,630 Individuals. J Gerontol Ser A. 2011;66A(5):487-492. doi:10.1093/gerona/glr001

6. Hall J. Pulmonary Ventilation. In: Guyton and Hall Textbook of Medical Physiology. 12th ed. ; 2011:474. 
https://archive.org/details/guytonandhalltextbookofmedicalphysiology12thed_202004/page /n493/mode/2up.

7. Hoffmann M, Kleine-Weber H, Schroeder S, et al. SARS-CoV-2 Cell Entry Depends on ACE2 and TMPRSS2 and Is Blocked by a Clinically Proven Protease Inhibitor. Cell. March 2020. doi:10.1016/j.cell.2020.02.052

8. Wang Q, Zhang Y, Wu L, et al. Structural and Functional Basis of SARS-CoV-2 Entry by Using Human ACE2. Cell. April 2020. doi:10.1016/j.cell.2020.03.045

9. Sims AC, Baric RS, Yount B, Burkett SE, Collins PL, Pickles RJ. Severe Acute Respiratory Syndrome Coronavirus Infection of Human Ciliated Airway Epithelia: Role of Ciliated Cells in Viral Spread in the Conducting Airways of the Lungs. J Virol. 2005;79(24):15511-15524. doi:10.1128/JVI.79.24.15511-15524.2005

10. Liu Y, Yan L-M, Wan L, et al. Viral dynamics in mild and severe cases of COVID-19. Lancet Infect Dis. 2020;0(0). doi:10.1016/S1473-3099(20)30232-2

11. Liu Y, Yang Y, Zhang C, et al. Clinical and biochemical indexes from 2019-nCoV infected patients linked to viral loads and lung injury. Sci China Life Sci. 2020;63(3):364-374. doi:10.1007/s11427-020-1643-8

12. Sohrabi C, Alsafi Z, O'Neill N, et al. World Health Organization declares global emergency: A review of the 2019 novel coronavirus (COVID-19). Int J Surg. 2020;76:71-76. doi:10.1016/j.ijsu.2020.02.034

13. Yang $\mathrm{X}, \mathrm{Yu} \mathrm{Y}, \mathrm{Xu}$ J, et al. Clinical course and outcomes of critically ill patients with SARS-CoV-2 pneumonia in Wuhan, China: a single-centered, retrospective, observational study. Lancet Respir Med. February 2020. doi:10.1016/S2213-2600(20)30079-5

14. Lu C, Liu X, Jia Z. 2019-nCoV transmission through the ocular surface must not be ignored. The Lancet. 2020;395(10224):e39. doi:10.1016/S0140-6736(20)30313-5

15. Peng X, Xu X, Li Y, Cheng L, Zhou X, Ren B. Transmission routes of 2019-nCoV and controls in dental practice. Int J Oral Sci. 2020;12(1):1-6. doi:10.1038/s41368-020-0075-9

16. CDC. Coronavirus Disease 2019 (COVID-19) - Transmission. Centers for Disease Control and Prevention.

https://www.cdc.gov/coronavirus/2019-ncov/prevent-getting-sick/how-covid-spreads.html. Published April 13, 2020. Accessed April 19, 2020.

17. Boone SA, Gerba CP. Significance of Fomites in the Spread of Respiratory and Enteric Viral Disease. Appl Environ Microbiol. 2007;73(6):1687-1696. doi:10.1128/AEM.02051-06

18. Kim Y-I, Kim S-G, Kim S-M, et al. Infection and Rapid Transmission of SARS-CoV-2 in Ferrets. Cell Host Microbe. April 2020. doi:10.1016/j.chom.2020.03.023

19. COVID-19 transmission in Mainland China is associated with temperature and humidity: a time-series analysis | medRxiv.

https://www.medrxiv.org/content/10.1101/2020.03.30.20044099v1. Accessed April 17, 2020.

20. Wang J, Tang K, Feng K, Lv W. High Temperature and High Humidity Reduce the Transmission of COVID-19. Rochester, NY: Social Science Research Network; 2020. https://papers.ssrn.com/abstract=3551767. Accessed April 17, 2020.

21. Sajadi MM, Habibzadeh P, Vintzileos A, Shokouhi S, Miralles-Wilhelm F, Amoroso A. Temperature, Humidity and Latitude Analysis to Predict Potential Spread and Seasonality for COVID-19. Rochester, NY: Social Science Research Network; 2020. https://papers.ssrn.com/abstract=3550308. Accessed April 17, 2020.

22. Notari A. Temperature dependence of COVID-19 transmission. April 2020. https://doi.org/10.1101/2020.03.26.20044529. Accessed April 17, 2020.

23. Qi H, Xiao S, Shi R, et al. COVID-19 transmission in Mainland China is associated with 
temperature and humidity: a time-series analysis. March 2020. https://doi.org/10.1101/2020.03.30.20044099. Accessed April 17, 2020.

24. National Academies of Sciences, Engineering, and Medicine. Rapid Expert Consultation on SARS-CoV-2 Survival in Relation to Temperature and Humidity and Potential for Seasonality for the COVID-19 Pandemic (April 7, 2020). April 2020. doi:10.17226/25771

25. Mecenas P, Bastos R, Vallinoto A, Normando D. Effects of temperature and humidity on the spread of COVID-19: A systematic review. medRxiv. April 2020:2020.04.14.20064923. doi:10.1101/2020.04.14.20064923

26. Schweizer C, Edwards RD, Bayer-Oglesby L, et al. Indoor time-microenvironment-activity patterns in seven regions of Europe. J Expo Sci Environ Epidemiol. 2007;17(2):170-181. doi:10.1038/sj.jes.7500490

27. Klepeis NE, Nelson WC, Ott WR, et al. The National Human Activity Pattern Survey (NHAPS): a resource for assessing exposure to environmental pollutants. J Expo Sci Environ Epidemiol. 2001;11(3):231-252. doi:10.1038/sj.jea.7500165

28. Moriyama M, Hugentobler WJ, Iwasaki A. Seasonality of Respiratory Viral Infections. Annu Rev Virol. March 2020. doi:10.1146/annurev-virology-012420-022445

29. Siddiqi HK, Mehra MR. COVID-19 Illness in Native and Immunosuppressed States: A Clinical-Therapeutic Staging Proposal. J Heart Lung Transplant. 2020;0(0). doi:10.1016/j.healun.2020.03.012

30. Channappanavar R, Perlman S. Pathogenic human coronavirus infections: causes and consequences of cytokine storm and immunopathology. Semin Immunopathol. 2017;39(5):529-539. doi:10.1007/s00281-017-0629-x

31. Ong E, Chan Y, Leong W, et al. A dynamic immune response shapes COVID-19 progression. Cell Host Microbe. 2020. doi:10.1016/j.chom.2020.03.021

32. Xu Z, Shi L, Wang Y, et al. Pathological findings of COVID-19 associated with acute respiratory distress syndrome. Lancet Respir Med. 2020;8(4):420-422. doi:10.1016/S2213-2600(20)30076-X

33. Knipe D, Howley P. Coronaviridae. In: Fields Virology. Vol 1. 6th ed. Lippincott Williams \& Wilkins; 2013.

https://archive.org/details/DavidM.KnipePeterHowleyFieldsVirologyKnipeFieldsVirology2Vo lumeSetLWW2013/mode/1up.

34. Gu J, Korteweg C. Pathology and Pathogenesis of Severe Acute Respiratory Syndrome. Am J Pathol. 2007;170(4):1136-1147. doi:10.2353/ajpath.2007.061088

35. Wu C, Chen X, Cai Y, et al. Risk Factors Associated With Acute Respiratory Distress Syndrome and Death in Patients With Coronavirus Disease 2019 Pneumonia in Wuhan, China. JAMA Intern Med. March 2020. doi:10.1001/jamainternmed.2020.0994

36. To KK-W, Tsang OT-Y, Leung W-S, et al. Temporal profiles of viral load in posterior oropharyngeal saliva samples and serum antibody responses during infection by SARS-CoV-2: an observational cohort study. Lancet Infect Dis. 2020;0(0). doi:10.1016/S1473-3099(20)30196-1

37. Lancet T. The gendered dimensions of COVID-19. The Lancet. 2020;395(10231):1168. doi:10.1016/S0140-6736(20)30823-0

38. Zhou F, Yu T, Du R, et al. Clinical course and risk factors for mortality of adult inpatients with COVID-19 in Wuhan, China: a retrospective cohort study. The Lancet. 2020;395(10229):1054-1062. doi:10.1016/S0140-6736(20)30566-3

39. Verity R, Okell LC, Dorigatti I, et al. Estimates of the severity of coronavirus disease 2019: a model-based analysis. Lancet Infect Dis. 2020;0(0). doi:10.1016/S1473-3099(20)30243-7

40. Wenham C, Smith J, Morgan R. COVID-19: the gendered impacts of the outbreak. The Lancet. 
2020;395(10227):846-848. doi:10.1016/S0140-6736(20)30526-2

41. Nikolich-Žugich J. The twilight of immunity: emerging concepts in aging of the immune system. Nat Immunol. 2018;19(1):10-19. doi:10.1038/s41590-017-0006-x

42. Qingxian C, Fengjuan C, Fang L, et al. Obesity and COVID-19 Severity in a Designated Hospital in Shenzhen, China. Rochester, NY: Social Science Research Network; 2020. doi:10.2139/ssrn.3556658

43. Haslam DW, James WPT. Obesity. The Lancet. 2005;366(9492):1197-1209. doi:10.1016/S0140-6736(05)67483-1 